\title{
PARTIAL AMINO ACID SEQUENCE FROM HORDEIN POLYPEPTIDE B1
}

\author{
by \\ JÜRGEN M. SCHMITT* \\ Department of Physiology, Carlsberg Laboratory \\ Gamle Carlsberg Vej 10, DK-2500 Copenhagen Valby \\ and \\ IB SVENDSEN \\ Department of Chemistry, Carlsberg Laboratory \\ Gamle Carlsberg Vej 10, DK-2500 Copenhagen Valby \\ * Present address: Institut für Botanik, Universität Würzburg, FRG.
}

Keywords: Barley, prolamin

Hordein polypeptide B1 has been cleaved with CNBr. Staphylococcus V8 protease and trypsin under denaturing conditions. Fragments have been isolated and examined by amino acid analysis and sequence determination. Amino acid residues were distributed irregularly along the $\mathrm{B} 1$ polypeptide chain with no indication of large Glx/Pro clusters. The single sequences presented account for about one fourth of the molecule. Two homologous but different tryptic peptides indicate either the presence of different $\mathrm{B} l$ molecules or internal sequence repetition.

\section{INTRODUCTION}

The prolamins of barley - hordeins - serve as seed storage proteins in the endosperm. This group of polypeptides is characterized by its solubility in aqueous alcohol and can be separated into several components using electrophoretic techniques (for recent reviews see 6, 13, 16, 26).
$\mathrm{N}$-terminal amino acid sequences have recently been obtained from total hordein $(2,20)$, partially purified hordein (22) and electrophoretically pure $\mathrm{C}$ hordein polypeptides $(20,24)$.

An evaluation of the $\mathrm{N}$-terminal sequences obtained from total hordein has led to the proposal, that at least the amino termini of the $\mathrm{C}$ hordein group are under evolutionary constraint

Abbreviations: SDS $=$ Sodium dodecyl sulfate; SV8 $=$ Staphylococcus V8 protease 
(20). This has been corroborated by the demonstration, that $\gamma_{3}$-gliadin from wheat $\mathrm{T}$. monococcum) and $\mathrm{C}$ hordein from barley are homologous (22).

$\mathrm{B} 1$ hordein, which is different from $\mathrm{C}$ hordein in amino acid composition and carboxy-terminal structure $(19,20)$ was blocked to $\mathrm{N}$-terminal analysis by dansylation (23) and Edman degradation (20). Bl hordein is of lower apparent molecular weight than $\mathrm{C}$ hordein but shares some chymotryptic peptides with $\mathrm{C}$ hordein (12), as judged by the "fingerprinting « technique.

In the present contribution we report on the amino acid sequences of some $\mathrm{CNBr}$ - and proteolytic fragments of $\mathrm{B} 1$ hordein. These data improve our understanding of the genetic relationship between $B$ and $C$ hordein as well as between prolamin of barley and other cereal species. Furthermore they will be used for comparison with the nucleotide sequences of a cloned reverse transcribed hordein messenger RNA molecule (5).

\section{MATERIALS AND METHODS}

\subsection{Isolation of hordein}

Hordein was isolated from barley seeds (Hordeum vulgare L.) cv. Bomi as described previously (20).

\subsection{Isolation of hordein polypeptide $B 1$}

Hordein polypeptide $\mathrm{BI}$ was isolated by ion exchange chromatography as described (19). In the scaled-up procedure used in the present study it was found that the fractions at the leading as well as at the trailing edge of the $\mathrm{B} 1$-peak contained minor impurities and only the center fractions were pooled. The purity of the isolated polypeptide BI was checked by gel electrophoresis in the presence of sodium dodecyl sulfate as described (19). For all calculations a molecular weight of 27,000 (12) was used.

\subsection{Alkylation of $\mathrm{SH}$-groups}

The fractions from the ion exchange column containing pure $\mathrm{Bl}$ polypeptide (cf. 2.2) were dried in vacuo. The samples were then redissolved to about $10 \mathrm{mg} \cdot \mathrm{ml}^{-1}$ in a buffer containing $0.13 \mathrm{~m}$-Tris, $2.7 \mathrm{~mm}$-EDTA and $6 \mathrm{~m}$-guanidine hydrochloride, adjusted to $\mathrm{pH} 7.5$, followed by reduction and alkylation as described in (9) and used for chemical or enzymatic cleavage.

\subsection{Fragmentation with cyanogen bromide}

Cyanogen bromide cleavage was carried out on 700 nmoles of $\mathrm{B} 1$ polypeptide as described by SEBaLD et al. (21). The reaction was stopped by addition of 5 volumes of water and subsequent freeze-drying.

\subsection{Cleavage with Staphylococcus protease $V 8$}

600 nmoles of $B 1$ polypeptide were dissolved in $24 \mathrm{ml}$ of a solution containing $50 \mathrm{~mm}$ ammonium bicarbonate and $0.2 \%$ SDS, $0.8 \mathrm{mg}$ Staphylococcus V8 protease (Miles Biochemicals) was added (7). Incubation time was 18 hours at $37^{\circ} \mathrm{C}$. The reaction was stopped by heating to $90^{\circ} \mathrm{C}$ for $5 \mathrm{~min}$. The sample was then lyophilized.

\subsection{Cleavage with trypsin}

600 nmoles of B1 polypeptide were dissolved in $40 \mathrm{ml}$ of a solution containing $6 \mathrm{M}$-urea and $125 \mathrm{~mm}$-sodium borate $\mathrm{pH} 9.7 \mathrm{mg}$ of cyclohexanedione was then added and the mixture incubated for 2 hours at $37^{\circ} \mathrm{C}$ to block the arginine residues (18). The reaction was stopped by addition of $4 \mathrm{ml}$ acetic acid and the sample was dialyzed against $1 \%$ acetic acid and freezedried.

The sample was then dissolved in $2 \mathrm{ml}$ of $8 \mathrm{M}$ urea and diluted with $5 \mathrm{ml}$ borate buffer to give final concentrations of 2 M-urea, 0.1 m-borate pH 8 (Wittman-Liebold, personal communication). To the turbid suspension $160 \mu \mathrm{g}$ trypsin was added at $\mathrm{t}=0$ and $\mathrm{t}=4$ hours $20 \mathrm{~min}$. The digestion at $37^{\circ} \mathrm{C}$ was monitored by following the appearance of new amino termini with fluorescamine (10). After 18 hours of incubation the mixture was lyophilized.

\subsection{Purification of proteolytic fragments}

The peptides from the SV8 digest were not completely soluble in the eluant. The amino acid composition of the insoluble residue is given in Table I. Following centrifugation the soluble 
J. M. Schmitt \& I. Svendsen: Partial sequence of hordein B1

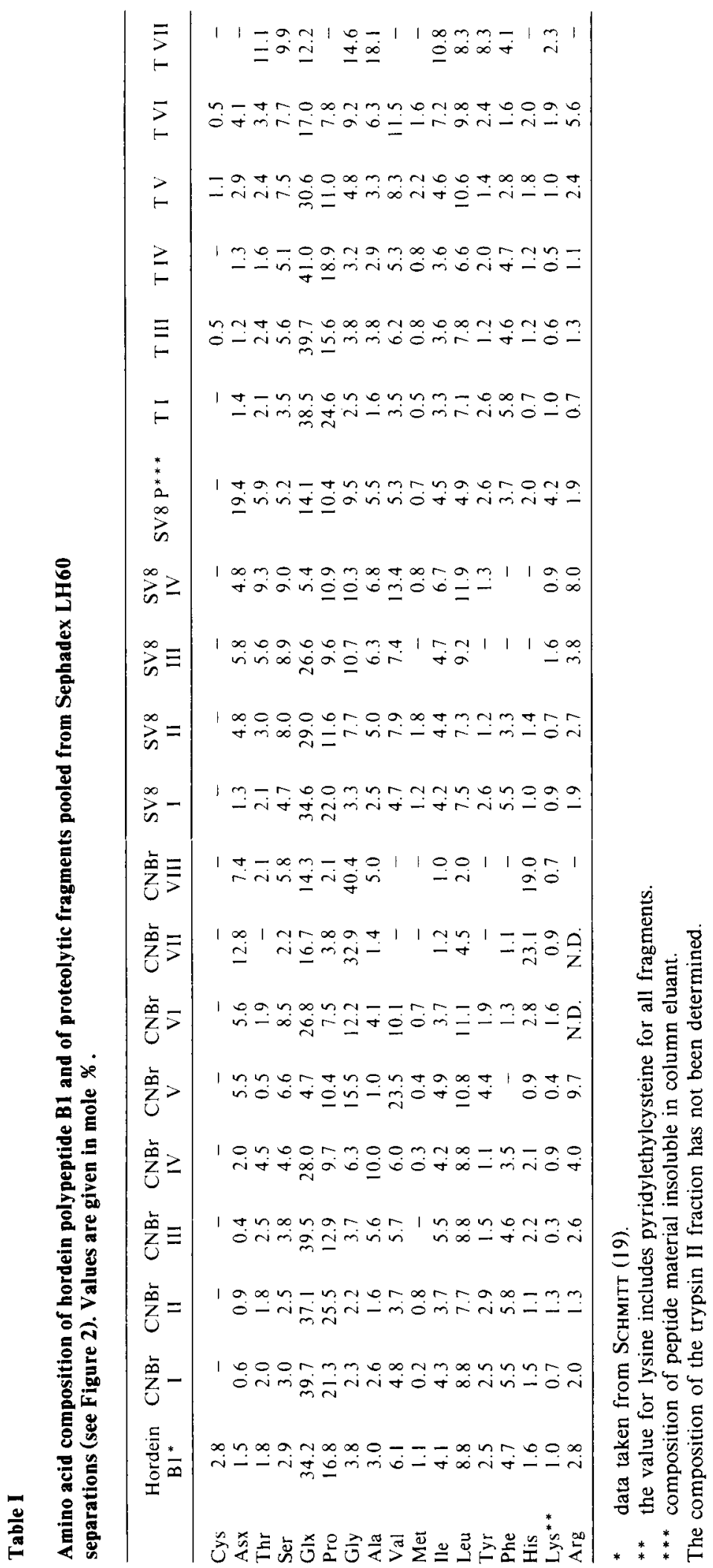

Carlsberg Res. Commun. Vol. 45, p. 549-555, 1980 


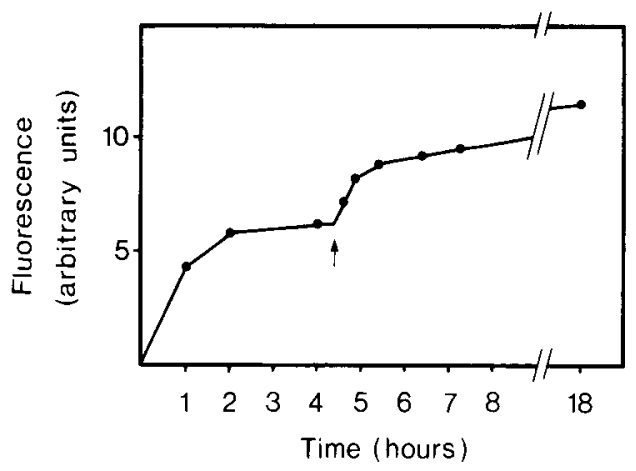

Figure 1. Hydrolysis of hordein Bl with trypsin in 0.1 m-borate buffer $\mathrm{pH} 8$, containing 2 m-urea. 1 denotes new addition of trypsin.

proteolytic fragments were separated on columns of Sephadex LH60 as described by GERBER et al. (11). After separation, the fractions were dried in vacuo and then taken up in $1 \mathrm{ml}$ of 0.1 M-ammonium hydroxide for absorbance measurements. Some fractions were only partially soluble under these conditions.

\subsection{Amino acid analysis}

Samples for amino acid analysis were hydrolyzed for 24 hours as described previously (19) and applied on a Durrum D-500 amino acid analyzer. In the chromatographic system used pyridylethylcysteine coeluted with lysine. No performic acid oxidation was carried out and the values are given without corrections.

\subsection{Sequence determination}

Automatic sequence determinations were performed with a Beckman model $890 \mathrm{C}$ liquid phase sequencer according to the method of EDMAN and BEGG (8). The procedure used has been described in details by JoHANSEN et al. (14). The samples were applied to the cup, dissolved in 58 per cent isopropanol or in a mixture of ethanol and formic acid ( 7 to $3 \mathrm{v} / \mathrm{v}$ ) and dried using the Beckman sample application subroutine programme 02772. Identification of PTH-amino acids was made by HPLC using a Hewlett Packard chromatograph, model $1084 \mathrm{~B}$ as described by Svendsen et al. (25). Additional information was obtained from thin layer chromato- graphy on polyamide sheets according to KULBE (15).

\section{RESULTS AND DISCUSSION}

Hordein polyptides are soluble in dilute alcohol but insoluble in aqueous media (17). We therefore chose cleavage methods which would function under denaturing conditions to ensure at least partial solubility of the substrate. The degradations were performed in formic acid/ water $(\mathrm{CNBr})$, or in buffers containing SDS (SV8 protease) or urea (trypsin). In the case of the proteases, the denaturants used have also a potentially inhibiting effect on the enzyme. This can be demonstrated by following the time course of the tryptic digestion (Figure 1). The exposure of new amino termini reached a plateau after about two hours, but reinitiation of digestion could be observed upon addition of fresh enzyme. In view of this fact it is possible that the enzymatic digestions are imcomplete.

Based on a molecular weight of 27.000 (12) for hordein $\mathrm{Bl}$ the molecules should contain three methionine residues and thus four peptides are to be expected upon cleavage with cyanogen bromide. One of these, the N-terminal peptide, is blocked to Edman degradation. A series of $\mathrm{CNBr}$-peptides has been isolated (Figure 2 and Table I) which in part must represent either incomplete reaction products or peptides derived from non-specific cleavage at tryptophan residues. Identical $\mathrm{N}$-terminal sequences were obtained with CNBr-peptides I, II and III emphasizing what is discussed above. The sequence of $\mathrm{CNBr}$-III is shown in Figure 3. That the largest $\mathrm{CNBr}$-fragments have a free $\mathrm{N}$-terminal amino acid would indicate that one of the methionine residues must be located close to the $\mathrm{N}$-terminus. $\mathrm{CNBr}-\mathrm{IV}$ and $\mathrm{CNBr}-\mathrm{VI}$ reacted negatively to Edman degradation as well as dansylation and may well represent blocked N-terminal peptides of different length.

One more peptide $(\mathrm{CNBr}-\mathrm{V})$ has been sequenced through 11 steps. Judged from the amino acid composition (Table I) this peptide probably consists of 19 amino acid residues.

Chromatography of the peptides obtained by cleavage with Staphylococcal protease gave rise to at least four peaks as shown in Figure 2 and Table I. The largest peak (SV8 I) did not respond 
J. M. Schmitt \& I. Svendsen: Partial sequence of hordein BI

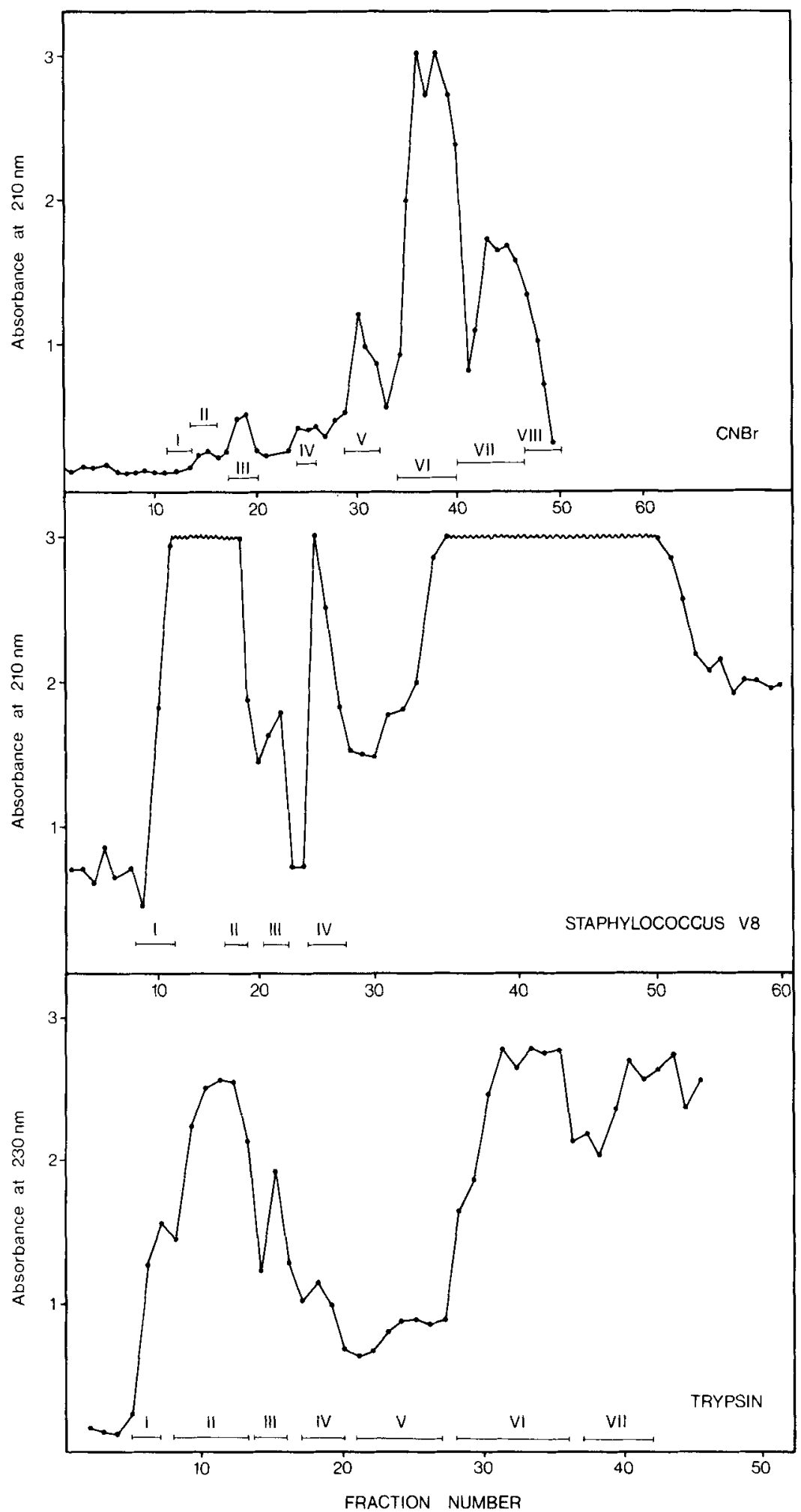

Figure 2. Separation on Sephadex LH60 (11) of peptides obtained by CNBr-cleavage, digestion with Staphylococcus V8 protease, and digestion with trypsin. The bars denote fractions pooled. 
10

$\mathrm{CNBr}$ III $\quad \mathrm{H}_{2} \mathrm{~N}-\mathrm{Leu}-\mathrm{Gln}-\mathrm{G} 1 \mathrm{n}-\mathrm{Ser}-\mathrm{Ser}-\mathrm{X}$-His-Val-Leu-Gln-Gln-G1n-Lys- X -G1n-Glu-Leu-Pro-Gln-

10

CNBr V

$: \mathrm{H}_{2} \mathrm{~N}-\mathrm{X}$-Ser-Va1-Asn-Va1-Pro-Leu-Tyr-Arg-Ile-(Leu)-

SV8 II

10

$: \mathrm{H}_{2} \mathrm{~N}-\mathrm{Gly}$-Val-Ser-Gln-Pro-GIn-Gln-G1n-Leu-Trp-Pro-Gln-Gln-(Va1)-Gly-Gly-X -Leu-

10

SV8 IV

$: \mathrm{H}_{2} \mathrm{~N}-\mathrm{A} 1 \mathrm{a}-\mathrm{Th} r-\mathrm{X}-\mathrm{Ser}-\mathrm{Ile}$-Ala-Leu-Arg-Thr-Leu-Pro-Val-

T III

10

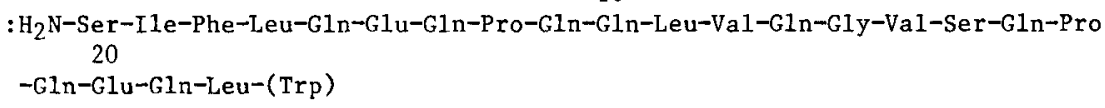

10

T IV

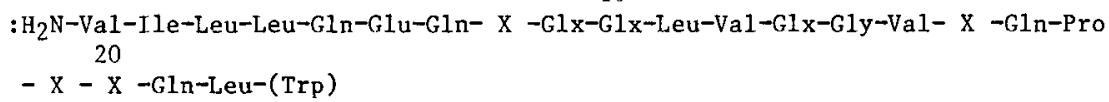

Figure 3. Partial amino acid sequences of $\mathrm{B} 1$ hordein peptides obtained by $\mathrm{CNBr}$-cleavage and digestion with Staphylococcus aureus V8 protease or trypsin.

Unidentified residues are denoted by an $\mathrm{X}$, residues whose identification is subjected to some uncertainty are given in brackets.

to Edman degradation and therefore represents either undigested hordein or a large $\mathrm{N}$-terminal peptide. Two peptides, SV8 II and IV, respectively, were clean and partly sequenced (see Figure 3). Peptide SV8 III was a mixture of two peptides which were rapidly washed out of the sequencer cup.

Digestion with trypsin under conditions where the arginine residues are blocked was dictated by the low content of lysine in hordein B1 (Table I). At a molecular weight of 27.000 three lysine residues are to be expected, and thus four tryptic peptides. The elution pattern of the resulting peptides is shown in Figure 2. Peaks I, II and V contained mixtures of peptides the sequences of which could not be resolved. However, peptides $\mathrm{T}$ III and T IV were sequenced for 23 steps (Figure 3). These sequences are homologous, but deviate at least in two positions (1 and 3). It is uncertain whether this homology expresses internal repetition of the sequence or homology between two different sequences of hordein Bl with identical Ctermini.
An overlap is noted between peptide SV8 II (residues 1 to 10) and tryptic peptide III (residues 14 to 23). This finding shows that the Gin found in position 13 in peptide trypsin III in part must be present as a glutamic acid.

No extensive sequence homologies between the $\mathrm{B} 1$ polypeptide and $\mathrm{C}$ hordein or prolamin sequences of other cereals could be detected (1, 2, $3,4,20,24)$. The identity of the pentapeptide Gln-Pro-Gln-Gln-Gln (SV8 II, 4-8) with a pentapeptide from $\gamma_{3}$-gliadin $(18-22)$ (3) is thought to be of little significance if not backed by other evidence, since Glx and Pro are the most abundant amino acids in both proteins.

\section{ACKNOWLEDGEMENTS}

The skilled technical assistance of Mss. BoDiL Corneliussen and Lone Sørensen in performing the amino acid analyses and operating the sequencer is gratefully acknowledged. One of us (IS) appreciates the fellowship provided by the Deutsche Forschungsgemeinschaft. 


\section{REFERENCES}

1. Autran, J.-C., E. J. L. Lew, C. C. Nimmo \& D. D. KASARDA: N-terminal amino acid sequencing of prolamins from wheat and related species. Nature 282, 527-529 (1979)

2. BieTz, J. A.: Cereal Chemistry, in press

3. Bietz, J. A., F. R. Huebner, J. E. Sanderson \& J. S. W ALL: Wheat gliadin homology revealed through $\mathrm{N}$-terminal amino acid sequence analysis. Cereal Chem. 54, 1070-1083 (1977)

4. Bietz, J. A., J. W. Paulis \& J. S. Wall: Zein subunit homology revealed through aminoterminal sequence analysis. Cereal Chem. 56, 327-332 (1979)

5. BRandt, A.: Cloning of double stranded DNA coding for hordein polypeptides. Carlsberg Res. Commun. 44, 255-267 (1979)

6. Cameron-Mills, V., A. Brandt \& J. Ingversen: The molecular biology of barley storage protein synthesis. In: Cereals for food and beverages. G. E. Inglett \& L. Munck, eds., Academic Press, 1980

7. Drapeau, G. R., Y. Bolly \& J. Houmard: Purification and properties of an extracellular protease of Staphylococcus aureus. J. Biol. Chem. 247, 6720-6726 (1972)

8. Edman, P. \& A. BeGG: A protein sequenator. Eur. J. Biochem. 1, 80-9l (1967)

9. Friedman, M., L. H. Krull \& J. F. Cavins: The chromatographic determination of cystine and cysteine residues in proteins as S- $\beta$ - (4-pyridylethyl)-cysteine. J. Biol. Chem. 245, 3868-3871 (1970)

10. Garesse, R., J. V. Castell, C. G. Vallejo \& R. MarCO: A fluorescamine-based sensitive method for the assay of proteinases, capable of detecting the initial cleavage steps of a protein. Eur. J. Biochem. 99, 253-259 (1979)

11. Gerber, G. E., R. J. AnderegG, W. C. Herliky, C. P. Gray, K. Biemann \& H. G. Khorana: Partial primary structure of bacteriorhodopsin: Sequencing methods for membrane proteins. Proc. Natl. Acad. Sci. USA 76, $227-$ 231 (1979)

12. Holder, A. A. \& J. Ingversen: Peptide mapping of the major components of in vitro synthesized barley hordein: evidence of structural homology. Carlsberg Res. Commun. 43, 177-184 (1978)

13. Ingversen, J., A. Brandt \& V. Cameron-Mills: The structure, biosynthesis and intracellular transport of barley endosperm reserve proteins. Abh. Akad. Wiss. DDR Abt. Math., Naturw., Techn. in press (1981)
14. Johansen, J. T., C. Overballe-Petersen, B. Martin, V. Hasemann \& I. Svendsen: The complete amino acid sequence of $\mathrm{Cu}, \mathrm{Zn}$ superoxide dismutase from Saccharomyces cerevisiae. Carlsberg Res. Commun. 44, 201-217 (1979)

15. KuLBE, K. D.: Rapid separation of phenylthiohydantoin (PTH) amino acids by thin-layer chromatography on polyamide glass plates. Anal. Biochem. 44, 548-558 (1971)

16. MifLin, B. J. \& P. R. Shewry: The biology and biochemistry of cereal seed prolamins. In: Seed protein improvement in cereals and grain leg. umes. International Atomic Energy Agency. pp. $137-158$ (1979)

17. Osborne, T. B.: The proteids of barley. J. Am. Chem. Soc. 17, 539-567 (1895)

18. Patthey, L. \& E. L. Smith: Reversible modification of arginine residues. J. Biol. Chem. 250 , 557-564 (1975)

19. Sснмгтt, J. M.: Purification of hordein polypeptides by column chromatography using volatile solvents. Carlsberg Res. Commun. 44, 431-438 (1979)

20. Schmitt, J. M. \& I. Svendsen: Amino acid sequences of hordein polypeptides. Carlsberg Res. Commun. 45, 143-148 (1980)

21. Sebald, W., E. Wachter \& A. Tzagoloff: Identification of amino acid substitutions of the dicyclohexylcarbodiimide-binding subunit of the mitochondrial ATPase complex from oligomy. cin-resistant mutants of Saccharomyces cerevisiae. Eur. J. Biochem. 100, 599-607 (1979)

22. Shewry, P. R., J.-C. Autran, C. C. Nimmo, E. J.-L. Lew \& D. D. Kasarda: N-terminal amino acid sequence homology of storage protein components from barley and a diploid wheat. Nature 286, 520-522 (1980)

23. Shewry, P. R., J. M. Field, M. A. Kirkman, A. J. Faulks \& B. J. Miflin: The extraction, solubility, and characterization of two groups of barley storage polypeptides. J. Exp. Bot. 31, 393-407 (1980)

24. Shewry, P. R., J. F. March \& B. J. Mifuin: Nterminal amino acid sequence of $\mathrm{C}$ hordein. Phytochem. 19, 2113-2115 (1980)

25. Svendsen, I., B. Martin \& I. Jonassen: Characteristics of Hiproly barley III. Amino acid sequences of two lysine-rich proteins. Carlsberg Res. Commun. 45, 79-85 (1980)

26. Wettstein, D. von: Biochemical and molecular genetics in the improvement of malting barley and brewers yeast. In: Proc. 17th European Brewery Convention Congress, Berlin 1979, pp. 587-629 